\title{
Testosterone prevents protein loss via the hepatic urea cycle in human
}

\author{
Teresa Lam ${ }^{1,2}$, Anne Poljak3, Mark McLean ${ }^{1,2}$, Neha Bahl ${ }^{1,4}$, Ken K Y Ho ${ }^{4,5}$ and \\ Vita Birzniece ${ }^{1,2,4,6}$ \\ ${ }^{1}$ School of Medicine, Western Sydney University, Penrith, New South Wales, Australia, ${ }^{2}$ Department of \\ Diabetes and Endocrinology, Blacktown Hospital, Blacktown, New South Wales, Australia, ${ }^{3}$ Bioanalytical \\ Mass Spectrometry Facility and School of Medical Sciences, University of New South Wales, New South \\ Wales, Australia, ${ }^{4}$ Garvan Institute of Medical Research, Sydney, New South Wales, Australia, ${ }^{5}$ Centres \\ of Health Research, Princess Alexandra Hospital, Brisbane, Queensland, Australia, and ${ }^{6}$ School of \\ Medicine, University of New South Wales, New South Wales, Australia
}

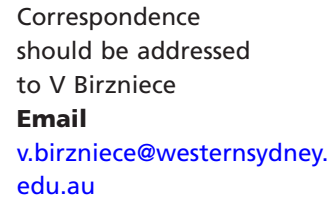

\section{Abstract}

Context: The urea cycle is a rate-limiting step for amino acid nitrogen elimination. The rate of urea synthesis is a true indicator of whole-body protein catabolism. Testosterone reduces protein and nitrogen loss. The effect of testosterone on hepatic urea synthesis in humans has not been studied.

Objective: To determine whether testosterone reduces hepatic urea production.

Design: An open-label study.

Patients and intervention: Eight hypogonadal men were studied at baseline, and after two weeks of transdermal testosterone replacement (Testogel, $100 \mathrm{mg} / \mathrm{day}$ ).

Main outcomes measures: The rate of hepatic urea synthesis was measured by the urea turnover technique using stable isotope methodology, with ${ }^{15} \mathrm{~N}_{2}$-urea as tracer. Whole-body leucine turnover was measured, from which leucine rate of appearance (LRa), an index of protein breakdown and leucine oxidation (Lox), a measure of irreversible protein loss, were calculated.

Results: Testosterone administration significantly reduced the rate of hepatic urea production (from $544.4 \pm 71.8$ to $431.7 \pm 68.3 \mu \mathrm{mol} / \mathrm{min} ; P<0.01)$, which was paralleled by a significant reduction in serum urea concentration. Testosterone treatment significantly reduced net protein loss, as measured by percent Lox/LRa, by $19.3 \pm 5.8 \%$ $(P<0.05)$. There was a positive association between Lox and hepatic urea production at baseline $\left(r^{2}=0.60, P<0.05\right)$ and after testosterone administration $\left(r^{2}=0.59, P<0.05\right)$.

Conclusion: Testosterone replacement reduces protein loss and hepatic urea synthesis. We conclude that testosterone regulates whole-body protein metabolism by suppressing the urea cycle.

\section{Introduction}

Testosterone increases muscle mass and strength and improves physical function in men (1). Declining levels of testosterone are associated with the development of sarcopaenia and frailty in men, and testosterone replacement in hypogonadal men increases muscle mass and strength $(2,3)$. However, tissue-specific biochemical mechanisms of androgen action are not fully understood.
Testosterone regulates amino acid availability, facilitating reutilization and increasing muscle protein accretion $(4,5)$. We have previously shown that the whole-body protein anabolic effects of testosterone are mediated through the liver $(6,7)$. In hypogonadal men, selective exposure of the liver to testosterone by oral administration reduces protein oxidation, a hallmark of catabolism.
() 2017 European Society of Endocrinology Printed in Great Britain
Published by Bioscientifica Ltd. 
This effect is indistinguishable to that of systemic (transdermal) testosterone administration. Thus, the liver is the primary site underpinning the anti-catabolic effect of testosterone. However, the intrahepatic biochemical pathways mediating the protein anabolic action of testosterone are unclear $(8,9)$.

Protein mass is constantly turning over in a dynamic process of breakdown and synthesis. Amino acids, derived from proteolysis, are either oxidized and irreversibly lost or resynthesized into protein. The liver is a major site of protein metabolism and degradation of amino acids, which is controlled by the urea cycle. Surplus $\alpha$-amino nitrogen derived from degradation of amino acids enters the urea cycle as ammonia and is converted to urea in hepatocytes and subsequently eliminated. This represents an irreversible loss of protein nitrogen (10). Hormones such as glucagon, glucocorticoids and growth hormone regulate urea cycle enzymes in the liver $(11,12)$. Early studies in rats also observed an inhibitory effect of testosterone on the arginine synthetase system, a key component of the urea cycle (13). Although it has since been demonstrated that testosterone increases nitrogen retention (14), evidence that testosterone suppresses urea production in humans is lacking.

The aim of this study was to determine in humans whether testosterone inhibits hepatic urea production. We employed stable isotope studies to investigate the effects of systemic testosterone administration on hepatic urea production in hypogonadal men. The leucine turnover technique was undertaken simultaneously to confirm that testosterone enhanced whole-body protein anabolism.

\section{Subjects and methods}

\section{Subjects}

Eight hypogonadal men were recruited from Endocrine Outpatients Clinics in Western Sydney, Australia. Inclusion criteria included males aged between 18 and 75 years with diagnosed primary or secondary hypogonadism, and adequate replacement of other hormones in the case of hypopituitarism. Exclusion criteria included patients with diabetes mellitus, malignancies, chronic renal or hepatic illnesses or taking medications known to interfere with the endocrine system. Out of eight patients, one had Klinefelter Syndrome, four had pituitary adenomas with hypogonadism and three had hypogonadism of unknown cause.

This study was approved by the Western Sydney Local Heath District Human Research Committee. The study was conducted in accordance with the principles of the Declaration of Helsinki. All participants gave written informed consent. The study was registered with the Australian and New Zealand Clinical Trials Registry (ACTRN 1261000577415).

\section{Study design}

In an open-label study, eight hypogonadal subjects were studied at baseline, and after two weeks of testosterone replacement by the transdermal route (Testogel; Besins Healthcare Australia Pty Ltd, $10 \mathrm{mg} / \mathrm{g}$ ), administered at a dose of $100 \mathrm{mg} /$ day. The main endpoint measurement was rate of hepatic urea synthesis. Other endpoint measurements included (1) whole-body leucine rate of appearance (LRa) and oxidation (Lox), which are indices of whole protein breakdown and oxidative loss, respectively, (2) energy expenditure, (3) body composition and (4) other biochemical markers of intervention, including serum levels of testosterone, urea, sex hormone-binding globulin (SHBG) and insulin-like growth factor. All participants were instructed to follow their usual diet and physical activity. Participants were studied after an overnight fast in the Blacktown Clinical School and Research Centre, Australia. At each visit, study blood samples were collected and placed on ice, and plasma and serum were separated and stored at $-80^{\circ} \mathrm{C}$ until analysis.

\section{Methods}

\section{Protein turnover}

The leucine turnover technique was used to measure whole-body protein metabolism. This method is based on the principle of steady-state kinetics whereby the rate of appearance of a substrate equals its rate of disposal. Leucine is either oxidized or re-incorporated into protein, and the fractional partitioning between these two pathways of disposal is determined from the fraction of infused isotope that appears in breath. The LRa and Lox were calculated as previously described (15). A-Ketoisocaproic acid (KIC) is formed when leucine undergoes transamination. It is used as a surrogate marker of leucine as it more accurately reflects the intracellular environment (16).

A $0.014 \mathrm{mg} / \mathrm{kg}$ priming dose of $\mathrm{NaH}^{13} \mathrm{CO}_{3}$ was given after an overnight fast, followed by a primed constant 3 - $\mathrm{h}$ infusion of $1-\left[{ }^{13} \mathrm{C}\right]$ leucine (prime $0.5 \mathrm{mg} / \mathrm{kg}$, infusion $0.5 \mathrm{mg} / \mathrm{kg} / \mathrm{h})(17,18) . \mathrm{NaH}^{13} \mathrm{CO}_{3}$ and $1-\left[{ }^{13} \mathrm{C}\right]$ leucine were obtained from Cambridge Isotope Laboratories (Woburn, MA). On each visit, blood and breath samples were 
collected before ( -10 and $0 \mathrm{~min})$ and during (140, 160 and $180 \mathrm{~min}$ ) the leucine infusion. Blood was placed on ice, and plasma was separated and stored at $-80^{\circ} \mathrm{C}$. As described by Nissen et al., KIC was extracted from plasma (19). Plasma KIC enrichment with ${ }^{13} \mathrm{C}$ was measured by gas chromatography-mass spectrometry (GCMS) (MSD 5971A, model 5890, Hewlett-Packard Co., Palo Alto, CA, USA). $\mathrm{CO}_{2}$ enrichment with ${ }^{13} \mathrm{C}$ in breath samples was measured at the University of Surrey, United Kingdom, on a Delta Plus XP isotope ratio mass spectrometer fitted with a Gas Bench II inlet system (Thermo Fisher Scientific). Based on previous experiences, our coefficients of variation $(\mathrm{CV})$ for LRa and Lox are 3.5 and 6.1\%, respectively (20).

\section{Urea synthesis}

The rate of urea synthesis was measured by the urea turnover technique using stable isotope methodology, with ${ }^{15} \mathrm{~N}_{2}$-Urea as tracer. Surplus $\alpha$-amino nitrogen derived from protein degradation enters the hepatic urea cycle as ammonia and is converted to urea. Thus, the rate of urea synthesis is a true indicator of net protein catabolism. Previously functional hepatic nitrogen clearance studies used blood $\alpha$-amino nitrogen concentrations and urinary urea-N excretion during infusion of amino acids (21). Our technique is based on an earlier protocol, which employs stable isotopes in the measurement of urea synthesis (22), offering time and sensitivity advantage.

After an overnight fast, a priming dose of ${ }^{15} \mathrm{~N}_{2}$-Urea $(3.4 \mathrm{mg} / \mathrm{kg}$; Cambridge Isotope Laboratories, Andover, MA, USA) was given, followed by a continuous infusion of the tracer at $0.34 \mathrm{mg} / \mathrm{kg} / \mathrm{h}$ for $4 \mathrm{~h}$. On each visit, blood samples were collected before ( -10 and $0 \mathrm{~min}$ ) and during $(120,180,210$ and $240 \mathrm{~min})$ the primed infusion, when steady state was reached. Plasma samples were collected into chilled tubes, separated immediately and stored at $-80^{\circ} \mathrm{C}$ until analysis. $\left[{ }^{13} \mathrm{C},{ }^{15} \mathrm{~N}_{2}\right]$-Urea was added to plasma samples as an internal control, and samples were prepared for analysis as previously described (23), with modifications. Briefly, plasma samples were treated with ethanol for one hour at $-20^{\circ} \mathrm{C}$ to precipitate proteins. The labeled and non-labeled urea in the samples was then converted to 2-hydroxypyrimidine using malonaldehyde bis(dimethyl acetal) and $\mathrm{HCl}$ during the one-hour incubation. The samples were evaporated to dryness in a Speed Vac concentrator for at least three hours, and reacted with MSTFA (N-methyl-N-(trimethyl-silyl) trifluoroacetamide) to form a trimethylsilyl derivative of 2-hydroxypyrimidine. Enrichments of $\left[{ }^{15} \mathrm{~N}_{2}\right]$ and $\left[{ }^{15} \mathrm{~N}_{1}\right]-$ urea were determined by GC-MS (MSD 5971A, model 5890, Hewlett-Packard Co.). Enrichments were expressed as tracer-to-tracee molar ratios and calculated from the deconvoluted enrichment peak ratios ( $\mathrm{m} / \mathrm{z}$ 155/153). Rate of hepatic urea production is an inverse measure of isotopic enrichment of $\left[{ }^{15} \mathrm{~N}_{2}\right]$-urea in blood and was calculated as a product of the rate of urea infusion and the tracer-to-tracee ratio. In our hands, day-to-day variation in urea production is $5.5 \%$, inter-assay $\mathrm{CV} 3.5 \%$ and intra-assay CV $1.8 \%$, assessed in four healthy men on two occasions one-week apart.

\section{Energy expenditure}

Whole-body energy expenditure and substrate oxidation were measured by indirect calorimetry using an opencircuit ventilated hood system (ParvoMedics, Sandy, UT, USA), calibrated against standard gases before each study. The participants rested in a supine position for at least $30 \mathrm{~min}$ and a clear plastic hood was placed over their heads for a period of $20 \mathrm{~min}$. Two measurements were taken and averaged.

\section{Body composition}

Fat mass (FM), lean body mass (LBM) and extracellular water (ECW) were assessed using Bioelectrical Impedance Spectroscopy (BIS; SFB7 analyzer, ImpediMed Ltd, Qld, Australia) (24). After $20 \mathrm{~min}$ of rest, two measurements were taken in the supine position, and the average was taken. Body cell mass (BCM), an estimate of muscle mass, was calculated by subtracting ECW from the LBM.

\section{Assays}

All samples for any individual were measured in the same assay run for each analyte. Concentrations of serum SHBG, testosterone and total PSA were measured by an electrochemiluminescence immunoassay (ECLIA) using a commercial assay kit (Roche Diagnostics). The CV for SHBG at $45.7 \mathrm{nmol} / \mathrm{L}$ was $2.1 \%$ and the $\mathrm{CV}$ for total testosterone at $0.087 \mathrm{nmol} / \mathrm{L}$ was $2.8 \%$. The $\mathrm{CV}$ for total PSA at $0.3 \mathrm{ng} / \mathrm{mL}$ was $2.4 \%$. Serum urea and albumin were measured photometrically. The $\mathrm{CV}$ for urea at $7.2 \mathrm{mmol} / \mathrm{L}$ was $1.2 \%$, and albumin at $49.6 \mathrm{~g} / \mathrm{L}$ was $0.4 \%$. The concentration of serum insulin was measured by chemiluminescent microparticle immunoassay (CMIA) and the $\mathrm{CV}$ at $55.08 \mu \mathrm{U} / \mathrm{mL}$ was $2.5 \%$. Serum creatinine was measured by a kinetic calorimetric assay and the $\mathrm{CV}$ at 
$72.9 \mu \mathrm{mol} / \mathrm{L}$ was $2.3 \%$. Serum IGF-I levels were measured by RIA after acid ethanol extraction, and the CVs for IGF-I were $8.3 \%$ at $14.7 \mathrm{nmol} / \mathrm{L}$ and $7.4 \%$ at $28.6 \mathrm{nmol} / \mathrm{L}$.

\section{Statistical analysis}

The treatment effects of testosterone on urea synthesis and protein turnover were assessed using paired $t$ tests. Results are expressed as mean \pm S.E.M., and a $P$ value $<0.05$ was considered to be significant. Linear regression analysis was used to correlate changes in urea synthesis with other endpoint measures. A linear mixed-effect model was used to determine the effect of changes in serum testosterone, LBM, BCM and IGF-1 on urea synthesis. Statistical analysis was undertaken using the statistical software package SPSS statistics, v22 (IBM Corporation) and RStudio (Boston, MA, USA).

\section{Results}

The mean age of participants was $49.1 \pm 4.9$ years. Their clinical, hormonal and metabolic characteristics at baseline, and after two weeks of transdermal testosterone therapy, are shown in Table 1. Administration of $100 \mathrm{mg} /$ day of transdermal testosterone for two weeks

Table 1 Clinical, hormonal and metabolic measures at baseline and after two weeks of transdermal testosterone treatment. Data are presented as mean \pm S.E.M.

\begin{tabular}{|c|c|c|c|}
\hline & Baseline & Testosterone & $P$ value \\
\hline Weight (kg) & $99.9 \pm 14$ & $101 \pm 14$ & $<0.05$ \\
\hline BMI & $31.5 \pm 3.9$ & $31.8 \pm 3.9$ & $<0.05$ \\
\hline $\begin{array}{l}\text { Lean body mass } \\
\text { (\% weight) }\end{array}$ & $69.1 \pm 2.1$ & $69.9 \pm 2.1$ & 0.32 \\
\hline Body cell mass $(\mathrm{kg})$ & $46.0 \pm 5.6$ & $46.6 \pm 5.1$ & 0.42 \\
\hline Extracellular water (L) & $22.0 \pm 3.0$ & $22.5 \pm 2.9$ & 0.19 \\
\hline SHBG (nmol/L) & $29.6 \pm 6.4$ & $27.3 \pm 5.2$ & 0.19 \\
\hline IGF-1 (nmol/L) & $17.6 \pm 2.9$ & $18.4 \pm 2.9$ & 0.3 \\
\hline Urea (mmol/L) & $6.0 \pm 0.5$ & $4.4 \pm 0.4$ & $<0.01$ \\
\hline Creatinine $(\mu \mathrm{mol} / \mathrm{L})$ & $77.9 \pm 3.3$ & $76.8 \pm 2.4$ & 0.57 \\
\hline Albumin (g/L) & $41.4 \pm 0.9$ & $40.9 \pm 8.0$ & 0.41 \\
\hline ALT (IU/L) & $28.8 \pm 2.1$ & $27.0 \pm 2.1$ & 0.47 \\
\hline AST (IU/L) & $27.6 \pm 2.7$ & $24.6 \pm 1.4$ & 0.37 \\
\hline Glucose (mmol/L) & $5.6 \pm 0.3$ & $5.7 \pm 0.2$ & 0.4 \\
\hline Insulin (IU/L) & $59.9 \pm 13.0$ & $77.9 \pm 35.2$ & 0.58 \\
\hline PSA (ng/mL) & $0.80 \pm 0.3$ & $0.94 \pm 0.2$ & 0.07 \\
\hline REE (kcal/day) & $1717.6 \pm 135.5$ & $1793.8 \pm 154.5$ & $<0.05$ \\
\hline Fox (mg/min) & $53.2 \pm 5.5$ & $54.0 \pm 10.1$ & 0.93 \\
\hline Cox (mg/min) & $116.6 \pm 13.3$ & $128.2 \pm 26.9$ & 0.64 \\
\hline
\end{tabular}

ALT, alanine aminotransferase; AST, aspartate aminotransferase; BMI, body mass index; Cox, carbohydrate oxidation; Fox, fat oxidation; IGF-1, insulin-like growth factor; PSA, prostate-specific antigen; REE, resting energy expenditure; SHBG, sex-hormone-binding globulin.

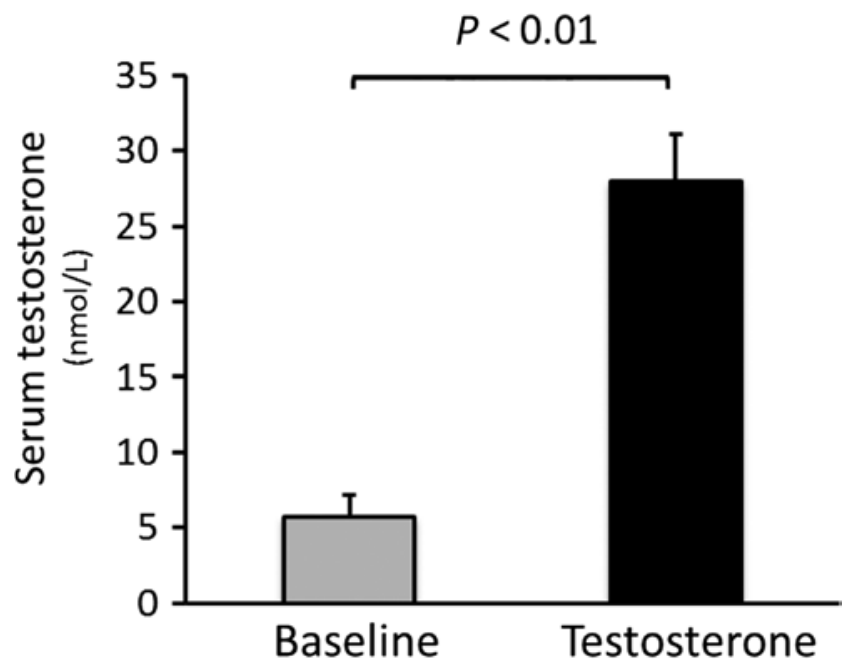

Figure 1

Serum testosterone levels at baseline and at the end of the two-week treatment period with transdermal testosterone (100 mg/day). Data are presented as mean \pm s.E.M.

increased serum levels of testosterone into the normal range (Fig. 1).

\section{Urea and protein turnover}

The baseline rate of hepatic urea synthesis was $544.4 \pm 71.8 \mu \mathrm{mol} / \mathrm{min}$. After testosterone administration for two weeks, urea production fell significantly by

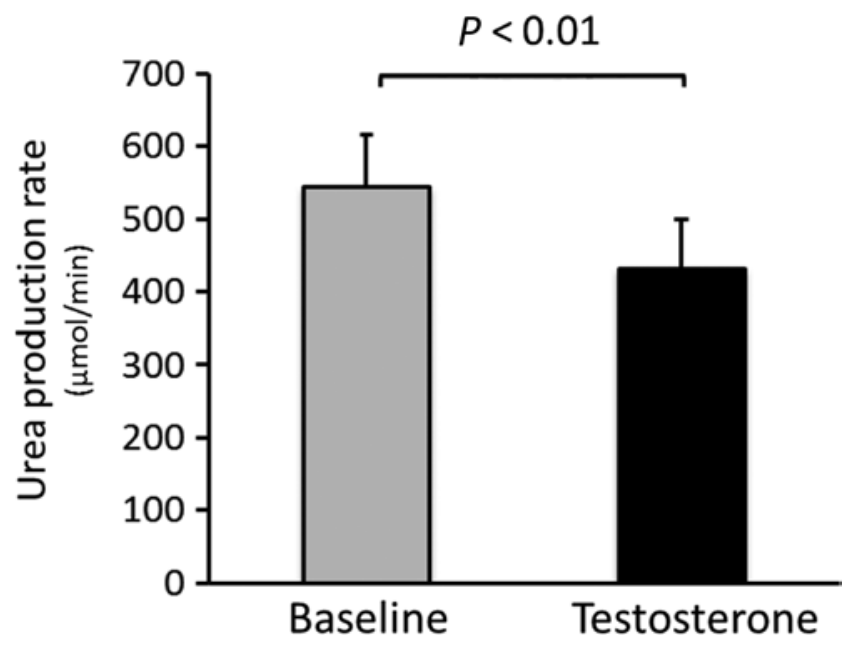

Figure 2

Urea synthesis at baseline and the end of the two-week treatment period with transdermal testosterone ( $100 \mathrm{mg} /$ day). Data are presented as mean \pm S.E.M. 
Table 2 Effects of testosterone on whole body protein turnover. Data are presented as mean \pm S.E.M.

\begin{tabular}{|c|c|c|c|}
\hline & Baseline & Testosterone & $P$ value \\
\hline LRa $(\mu \mathrm{mol} / \mathrm{min})$ & $211.1 \pm 22.6$ & $215.8 \pm 26.0$ & 0.57 \\
\hline $\operatorname{Lox}(\mu \mathrm{mol} / \mathrm{min})$ & $42.8 \pm 5.2$ & $35.9 \pm 6.0$ & $<0.05$ \\
\hline Lox ( $\%$ from Ra) & $20.5 \pm 1.5$ & $16.4 \pm 1.6$ & $<0.05$ \\
\hline
\end{tabular}

Lox, leucine oxidation (a measure of irreversible loss of protein); LRa, leucine rate of appearance (a measure of protein breakdown).

$21 \pm 5 \%(P<0.01$; Fig. 2$)$ accompanied by a fall $(P<0.01)$ in serum urea concentration (Table 1).

Testosterone administration did not significantly affect LRa, a measure of protein turnover (Table 2). Leucine oxidized as a proportion of LRa (percent Lox/ LRa), which represents the proportion of amino acids that are irreversibly lost when adjusted for changes in protein turnover, was significantly reduced by $19.3 \pm 5.8 \%$ $(P<0.05)$ after testosterone administration.

\section{Other endpoint measures}

On average, the weight of participants increased by $1.1 \pm 0.4 \mathrm{~kg}$ (Table 1). Two weeks of testosterone administration did not significantly change any of the body composition parameters. After two weeks of testosterone administration, there was a significant increase in resting energy expenditure by $76.2 \pm 26.4 \mathrm{kcal} /$ day $(P<0.05)$. There were no significant changes in the rates of fat or carbohydrate oxidation. There were no significant changes in any of the measured endocrine markers, including serum levels of SHBG, IGF-1, glucose or insulin. Similarly, testosterone did not significantly change levels of liver transaminases (AST and ALT), albumin, creatinine or prostate-specific antigen (Table 1).

\section{Association between urea synthesis and other end point measurements}

The rate of hepatic urea production was significantly correlated with net Lox, a maker of irreversible loss of protein before $\left(r^{2}=0.60, P<0.05\right.$; Fig. 3A) and after testosterone replacement $\left(r^{2}=0.59, P<0.05\right)$. The slopes of the relationship between urea production and Lox were similar before and during the treatment $(P=0.34)$. Hepatic urea production significantly correlated with serum urea concentration at baseline and during testosterone administration $(P<0.05$; Fig. $3 \mathrm{~B})$. The reduction in hepatic urea synthesis could not be predicted by changes in serum testosterone, LBM, BCM or IGF-1 by a linear mixed-effects model.
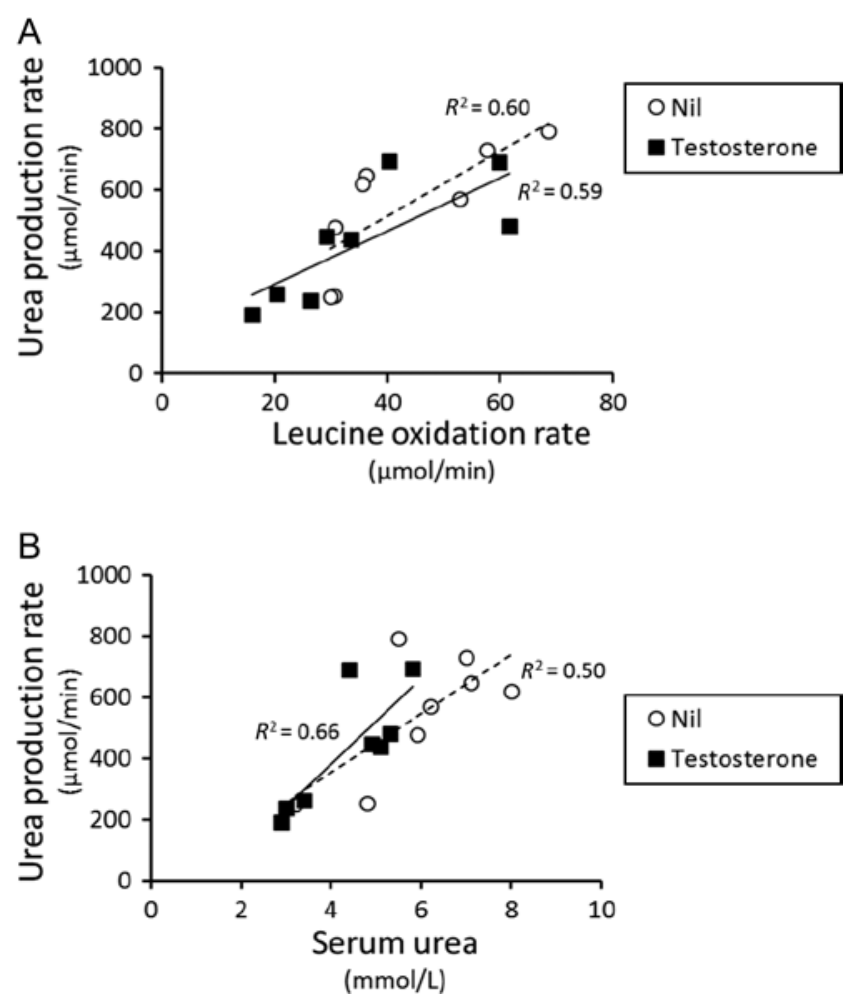

Figure 3

(A) Association between hepatic urea production and leucine oxidation (Lox) at baseline (broken line) and at the end of the testosterone administration (solid line). (B) Association between hepatic urea production and serum urea concentration at baseline (broken line) and at the end of the testosterone administration (solid line).

\section{Discussion}

This study is the first to investigate the effects of testosterone on hepatic urea production in humans. We show that testosterone replacement significantly reduces hepatic urea production in hypogonadal men. This occurs in parallel with a significant fall in leucine oxidation, an index of irreversible loss of whole-body protein. We provide evidence that testosterone induction of protein anabolism in humans is most likely mediated by inhibition of the hepatic urea cycle, thereby conserving amino acids for protein synthesis (Fig. 4).

Hormones that cause catabolism, such as glucocorticoids and glucagon, stimulate urea synthesis, as reflected in an enhancement of functional hepatic nitrogen clearance (25). At the in vitro level, glucocorticoids increase gene expression of enzymes promoting urea synthesis (12). Hepatic glucocorticoid receptors control urea cycle function via transcriptional activation of the 


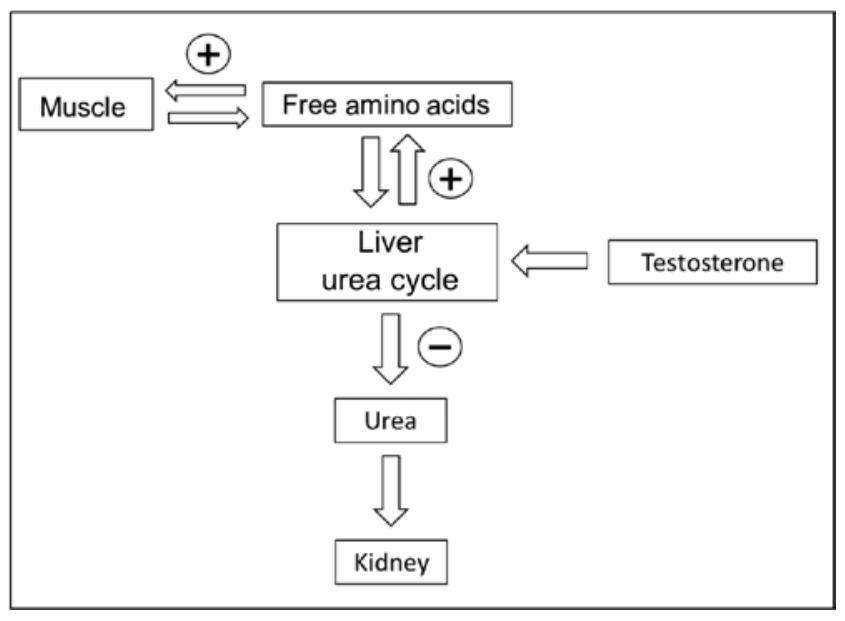

Figure 4

Protein metabolism: amino acids derived from proteolysis in muscle partake in a shuttle to and from the liver with a proportion metabolized irreversibly to urea in the liver and excreted by the kidney. We propose that testosterone reduces amino acid loss via inhibition of the hepatic urea cycle.

Arginase 1 gene (26). Similarly, treatment with glucagon upregulates enzymes of the urea cycle in cultured rat hepatocytes such as carbamoyl phosphate synthetase, arginosuccinase and arginase (12). The reverse occurred when rats were treated with growth hormone, an anabolic hormone (11). However, the effect of testosterone is not established, and the evidence from animal studies is contradictory. In overiectomized female rats, testosterone treatment for ten days significantly reduced arginine synthetase activity, a key enzymatic component of the urea cycle (27). However, intraperitoneal injection of testosterone into female rats has also been shown to increase liver arginase activity (28). Thus, early work in female rats report discordant effects of testosterone on urea cycle enzyme activity. Although it is long established that testosterone is nitrogen sparing (14), biochemical evidence that testosterone inhibits the urea cycle has been lacking. We here provide unequivocal evidence for a direct effect of testosterone on the hepatic urea cycle in humans. We found that restoring testosterone levels into the normal range reduced hepatic urea production by approximately $20 \%$ in hypogonadal men.

Androgens increase muscle mass and strength (29). Although androgens regulate muscle protein economy indirectly through the urea cycle, they also act directly on muscle stimulating myoblast growth and differentiation, inducing muscle fiber hypertrophy (30). The extent to which the indirect and direct actions of androgens contribute to muscle mass has been a subject of great interest and explored by utilizing muscle-specific AR-knockout models. These models provide evidence of cell type-specific effects of AR activation in the regulation of muscle anabolism. Studies in myocyte-specific AR-knockout (mARKO) mice show surprising preservation of skeletal muscle mass, with muscle loss restricted only to the highly androgen-sensitive levator ani muscle $(31,32)$. Conversely, studies in mARKO mice on the effects of orchidectomy (31), and global AR-knockout mice, show a significant but selective reduction in the mass of hind limb skeletal muscles (33). This indicates that androgen receptor activation purely in myocytes is not sufficient to induce muscle anabolism. It has been proposed that androgen effects on muscle may be mediated through other cell types, such as satellite cells, myofibroblasts and motor neurons $(34,35)$, via non-genomic pathways (36), or through testosterone aromatization to estradiol (37). Thus, the regulation of muscle mass by androgens is complex, involves direct, indirect and paracrine mechanisms. We now add an additional component to this system by demonstrating that testosterone action on the liver reduces loss of amino acid nitrogen, potentially increasing the pool available for muscle anabolism.

There is a linear relationship between the hepatic urea synthesis rate and the blood amino acid concentration. Therefore, a fall in amino acid concentration in the blood (due to e.g. decrease in protein breakdown in the muscle) may reduce the rate of urea production. However, this did not occur, as we provide evidence that protein breakdown (LRa) was unaffected by testosterone replacement. Thus, it is highly unlikely that the reduced urea production in our study would have resulted from a reduction in amino acid availability. Nevertheless, it would be of interest to measure the amino nitrogen concentrations. Previous research, however, reports increase in amino acid plasma concentration during testosterone replacement (38). As amino acid availability in blood is expected to increase with testosterone administration, this would result in an increase in urea production. However, the reverse was found in our study. Therefore, this provides strong evidence that testosterone acts on the liver directly to reduce urea production.

The leucine and urea turnover techniques are established methods for quantifying whole-body protein metabolism. Both methods quantify the oxidative metabolism of amino acids by tracking the disposal of labeled molecular constituents of amino acid. The leucine turnover technique tracks the metabolic fate of the carbon moieties of amino acids, providing a measure of whole-body protein oxidative loss. The urea turnover 
technique tracks nitrogen through the generation of urea in the liver. As these are processes common to amino acid oxidative catabolism, the finding of a strong relationship between rates of leucine oxidation and urea production in the present study is a predictable outcome. Not only does this association validate the integrity of both methodologies in our hands it also confirms that leucine and urea turnovers provide internally concordant indices of whole-body protein turnover.

We have previously reported that the inhibition of whole-body leucine oxidative loss by testosterone in hypogonadal men is equal between oral and transdermal delivery (6). Because rates of Lox and urea production are measures of amino acid catabolism, this means that testosterone delivered by the oral and transdermal routes is expected to reduce urea production equally. Thus, androgen exposure to the liver underlies the mechanistic prevention of whole-body protein catabolism by testosterone. Strong evidence for the importance of this mechanism comes from our study findings that solely hepatic testosterone exposure delivered by the oral route reduces catabolism in hypopituitary men with hypogonadism and in postmenopausal women $(6,7)$. As the effect of the liver-targeted testosterone was only evident in the presence of growth hormone (GH) (6), full testosterone effect on protein metabolism is expected in the current study, as these patients had isolated hypogonadism and no impairment or disturbance of GH secretion. Thus, in a GH-replete subject with hypogonadism, testosterone reduces whole-body protein loss by affecting hepatic urea cycle. These findings open a novel approach of targeting the hepatic urea cycle to enhance whole-body protein anabolism. This liver-targeted approach has an advantage in situations where systemic testosterone treatment poses a health risk in men or virilization in women. Thus, there is a potential to develop liver-targeted testosterone as a novel, safe and cost-effective treatment for sarcopenia in both men and women.

This study has some limitations, such as the small sample size and that it was not blinded or placebo controlled. However, as each patient served as its own control, this short-term intervention causing substantial changes in hepatic urea production in the absence of any changes in lifestyle and body composition provides strong evidence of a biological effect. The outcome measures are objective and provide proof of principle that in humans, testosterone reduces hepatic urea production in parallel with a reduction in an independent measure of whole-body protein loss. The results are unlikely to occur by chance as reduction in urea synthesis $(-21 \%)$ exceeds that of the day-to-day reproducibility of the method (CVs 5.5\%).
In summary, we provide the first evidence that testosterone stimulates protein anabolism by acting on the liver to reduce irreversible nitrogen loss through the urea cycle. These findings are highly significant as may lead to the future use of liver-targeted testosterone therapy as a potential intervention in the treatment of sarcopaenia, without the adverse effects of systemic testosterone.

Declaration of interest

The authors declare that there is no conflict of interest that could be perceived as prejudicing the impartiality in this study.

Funding

This research did not receive any specific grant from any funding agency in the public, commercial or not-for-profit sector.

\section{Author contribution statement}

Dr Teresa Lam assisted with study visit conduct, data analysis and wrote the manuscript; Dr Anne Poljak developed stable isotope method, assisted with sample and data analysis and contributed to manuscript preparation; Prof Mark McLean developed research concept, recruited patients and contributed to manuscript preparation; Dr Neha Bahl developed assay method, assisted with sample analysis and contributed to manuscript preparation; Prof Ken Ho developed research concept and contributed to manuscript preparation; Dr Vita Birzniece developed research concept, performed study visits, assisted with data analysis and contributed to manuscript preparation.

\section{Acknowledgements}

The authors would like to acknowledge research nurse Meredith Jamieson for clinical assistance, Dr David Chipps, Dr Jane Holmes-Walker, Dr Naswrin Moin and Dr Tien-Ming Hng for assistance with patient recruitment and Prof Margot Umpleby and Dr Nicola Jackson from University of Surrey, UK, for assistance with mass spectrometry. They also thank Surya Sutanto and the Endocrinology Lab, Royal Prince Alfred Hospital, Sydney, Australia, for providing laboratory assistance and Prof. Glenn Stone from Western Sydney University, Australia, for providing statistical assistance.

\section{References}

1 Bhasin S, Woodhouse L, Casaburi R, Singh AB, Mac RP, Lee M, Yarasheski KE, Sinha-Hikim I, Dzekov C, Dzekov J et al. Older men are as responsive as young men to the anabolic effects of graded doses of testosterone on the skeletal muscle. Journal of Clinical Endocrinology and Metabolism 200590 678-688. (doi:10.1210/jc.2004-1184)

2 Bhasin S, Storer TW, Berman N, Yarasheski KE, Clevenger B, Phillips J, Lee WP, Bunnell TJ \& Casaburi R. Testosterone replacement increases fat-free mass and muscle size in hypogonadal men. Journal of Clinical Endocrinology and Metabolism 199782 407-413. (doi:10.1210/ jcem.82.2.3733)

3 Snyder PJ, Peachey H, Berlin JA, Hannoush P, Haddad G, Dlewati A, Santanna J, Loh L, Lenrow DA, Holmes JH et al. Effects of testosterone replacement in hypogonadal men. Journal of Clinical Endocrinology and Metabolism 200085 2670-2677. (doi.org/10.1210/jc.85.8.2670)

4 Ferrando AA, Tipton KD, Doyle D, Phillips SM, Cortiella J \& Wolfe RR. Testosterone injection stimulates net protein synthesis but not tissue amino acid transport. American Journal of Physiology 1998275 E864-E871.

5 Kochakian CD. Comparison of protein anabolic property of various androgens in the castrated rat. American Journal of Physiology 1950 $16053-61$ 
6 Birzniece V, Meinhardt UJ, Umpleby MA, Handelsman DJ \& Ho KK. Interaction between testosterone and growth hormone on whole-body protein anabolism occurs in the liver. Journal of Clinical Endocrinology and Metabolism 201196 1060-1067. (doi:10.1210/jc.2010-2521)

7 Birzniece V, Umpleby MA, Poljak A, Handelsman DJ \& Ho KK. Oral lowdose testosterone administration induces whole-body protein anabolism in postmenopausal women: a novel liver-targeted therapy. European Journal of Endocrinology 2013169 321-327. (doi:10.1530/EJE-13-0406)

8 Eagon PK, Elm MS, Stafford EA \& Porter LE. Androgen receptor in human liver: characterization and quantitation in normal and diseased liver. Hepatology 199419 92-100. (doi:10.1002/hep.1840190116)

9 Eisenfeld AJ \& Aten RF. Estrogen receptors and androgen receptors in the mammalian liver. Journal of Steroid Biochemistry 198727 1109-1118. (doi:10.1016/0022-4731(87)90197-X)

10 Lieberman M, Marks AD \& Smith CM. Marks' Basic Medical Biochemistry. Philadelphia, PA, USA: Wolters Kluwer Health/Lippincott Williams \& Wilkins, 2009.

11 McLean P \& Gurney MW. Effect of adrenalectomy and of growth hormone on enzymes concerned with urea synthesis in rat liver. Biochemical Journal 196387 96-104. (doi:10.1042/bj0870096)

12 Vilstrup H. On urea synthesis - regulation in vivo. Danish Medical Bulletin 198936 415-429.

13 Brown GW Jr \& Cohen PP. Comparative biochemistry of urea synthesis. I. Methods for the quantitative assay of urea cycle enzymes in liver. Journal of Biological Chemistry 1959234 1769-1774.

14 Kenyon AT, Knowlton K, Sandiford I, Koch FC \& Lotwin G. A comparative study of the metabolic effects of testosterone propionate in normal men and women and in eunuchoidism. Endocrinology 1940 26 26-45. (doi:10.1210/endo-26-1-26)

15 Matthews DE, Motil KJ, Rohrbaugh DK, Burke JF, Young VR \& Bier DM. Measurement of leucine metabolism in man from a primed, continuous infusion of 1-[1-3C]leucine. American Journal of Physiology 1980238 E473-E479.

16 Horber FF, Horber-Feyder CM, Krayer S, Schwenk WF \& Haymond MW. Plasma reciprocal pool specific activity predicts that of intracellular free leucine for protein synthesis. American Journal of Physiology 1989257 E385-E399.

17 Hoffman DM, Pallasser R, Duncan M, Nguyen TV \& Ho KK. How is whole body protein turnover perturbed in growth hormone-deficient adults? Journal of Clinical Endocrinology and Metabolism $1998 \mathbf{8 3}$ 4344-4349. (doi:10.1210/jc.83.12.4344)

18 Wolthers T, Hoffman DM, Nugent AG, Duncan MW, Umpleby M \& Ho KK. Oral estrogen antagonizes the metabolic actions of growth hormone in growth hormone-deficient women. American Journal of Physiology: Endocrinology and Metabolism 2001281 E1191-E1196.

19 Nissen SL, Miles JM, Gerich JE \& Haymond MW. Regulation of alpha-ketoisocaproate binding to albumin in vivo by free fatty acids. American Journal of Physiology 1982242 E67-E71.

20 Burt MG, Gibney J, Hoffman DM, Umpleby AM \& Ho KK. Relationship between GH-induced metabolic changes and changes in body composition: a dose and time course study in GH-deficient adults. Growth Hormone and IGF Research 200818 55-64. (doi:10.1016/j.ghir.2007.07.005)

21 Hamberg O \& Vilstrup H. A rapid method for determination of hepatic amino nitrogen to urea nitrogen conversion ('the Functional Hepatic Nitrogen Clearance'). Scandinavian Journal of Clinical and Laboratory Investigation $1994 \mathbf{5 4}$ 377-383. (doi:10.3109/00365519409088437)

22 Wolfe RR, Goodenough RD, Wolfe MH, Royle GT \& Nadel ER. Isotopic analysis of leucine and urea metabolism in exercising humans. Journal of Applied Physiology: Respiratory, Environmental and Exercise Physiology 198252 458-466.
23 Kessler A \& Siekmann L. Measurement of urea in human serum by isotope dilution mass spectrometry: a reference procedure. Clinical Chemistry 199945 1523-1529.

24 Birzniece V, Khaw CH, Nelson AE, Meinhardt U \& Ho KK. A critical evaluation of bioimpedance spectroscopy analysis in estimating body composition during GH treatment: comparison with bromide dilution and dual X-ray absorptiometry. European Journal of Endocrinology 2015172 21-28. (doi:10.1530/EJE-14-0660)

25 Grofte T, Jensen DS, Greisen J, Tygstrup N \& Vilstrup H. Growth hormone and insulin-like growth factor-I counteracts established steroid catabolism in rats by effects on hepatic amino-N degradation. Journal of Hepatology 200135 700-706. (doi:10.1016/S01688278(01)00255-0)

26 Okun JG, Conway S, Schmidt KV, Schumacher J, Wang X, de Guia R, Zota A, Klement J, Seibert O, Peters A et al. Molecular regulation of urea cycle function by the liver glucocorticoid receptor. Molecular Metabolism 20154 732-740. (doi:10.1016/j.molmet.2015.07.006)

27 Riggs TR \& Walker LM. Diminution of arginine synthetase activity in livers of rats treated with testosterone propionate. Endocrinology 1963 73 830-831. (doi:10.1210/endo-73-6-830)

28 Kochakian CD. Anabolic-Androgenic Steroids. Heidelberg, Germany: Springer-Verlag, 1976.

29 Basualto-Alarcon C, Varela D, Duran J, Maass R \& Estrada M. Sarcopenia and androgens: a link between pathology and treatment. Frontiers in Endocrinology 20145 217. (doi.org/10.3389/ fendo.2014.00217)

30 Herbst KL \& Bhasin S. Testosterone action on skeletal muscle. Current Opinion in Clinical Nutrition and Metabolic Care 20047 271-277. (doi:10.1097/00075197-200405000-00006)

31 Chambon C, Duteil D, Vignaud A, Ferry A, Messaddeq N, Malivindi R, Kato S, Chambon P \& Metzger D. Myocytic androgen receptor controls the strength but not the mass of limb muscles. PNAS 2010 107 14327-14332. (doi:10.1073/pnas.1009536107)

32 Ophoff J, Van Proeyen K, Callewaert F, De Gendt K, De Bock K, Vanden Bosch A, Verhoeven G, Hespel P \& Vanderschueren D. Androgen signaling in myocytes contributes to the maintenance of muscle mass and fiber type regulation but not to muscle strength or fatigue. Endocrinology 2009150 3558-3566. (doi:10.1210/en.20081509)

33 MacLean HE, Chiu WS, Notini AJ, Axell AM, Davey RA, McManus JF, Ma C, Plant DR, Lynch GS \& Zajac JD. Impaired skeletal muscle development and function in male, but not female, genomic androgen receptor knockout mice. FASEB Journal 200822 2676-2689. (doi:10.1096/fj.08-105726)

34 Monks DA, O’Bryant EL \& Jordan CL. Androgen receptor immunoreactivity in skeletal muscle: enrichment at the neuromuscular junction. Journal of Comparative Neurology 2004473 59-72. (doi:10.1002/cne.20088)

35 Chen Y, Zajac JD \& MacLean HE. Androgen regulation of satellite cell function. Journal of Endocrinology 2005186 21-31. (doi:10.1677/ joe.1.05976)

36 Foradori CD, Weiser MJ \& Handa RJ. Non-genomic actions of androgens. Frontiers in Neuroendocrinology 200829 169-181. (doi:10.1016/j.yfrne.2007.10.005)

37 Svensson J, Moverare-Skrtic S, Windahl S, Swanson C \& Sjogren K. Stimulation of both estrogen and androgen receptors maintains skeletal muscle mass in gonadectomized male mice but mainly via different pathways. Journal of Molecular Endocrinology 201045 45-57. (doi:10.1677/JME-09-0165)

38 Ackermann PG \& Kheim T. The effect of testosterone on plasma amino acid levels in elderly individuals. Journals of Gerontology 1964 19 207-214. (doi:10.1093/geronj/19.2.207)

Received 18 October 2016

Revised version received 5 January 2017

Accepted 25 January 2017 